\title{
Ionic Liquid-Catalyzed Preparation of Aromatic Polyamides Containing Phthalazinone Moiety
}

\author{
Saeed Zahmatkesh \\ Department of Science, Payame Noor University, Tehran 19395-4697, Iran \\ Correspondence should be addressed to Saeed Zahmatkesh, zahmatkesh1355@yahoo.com
}

Received 9 August 2012; Accepted 30 August 2012

Academic Editors: P. Dobrzynski, A. Hashidzume, and B. Kiskan

Copyright ( 2012 Saeed Zahmatkesh. This is an open access article distributed under the Creative Commons Attribution License, which permits unrestricted use, distribution, and reproduction in any medium, provided the original work is properly cited.

\begin{abstract}
An unsymmetrical heterocyclic dicarboxylic acid monomer, 4-[4-(4-carboxy phenoxy)-naphthyl]-2-(4-carboxyphenyl) phthalazin-1-one (1) was successfully prepared. A series of polyamides containing phthalazinone were prepared from the prepared dicarboxylic acid with various aromatic diamines in an ionic liquid (IL) as a green, safe, and eco-friendly medium and also reactions catalysis agent. Evaluation of data shows that IL is the better polyamidation medium than the reported method and the catalysis stands on the higher inherent viscosities and yields of the obtained PAs and the rate of polymerizations beyond the greener reaction conditions and deletion of some essential reagents in conventional manner. Characterization was performed by means of ${ }^{1} \mathrm{H}-\mathrm{NMR}$ and FT-IR spectroscopy, elemental analysis, thermogravimetric analysis, and differential scanning calorimetric techniques. Molecular weights of the obtained polyamides were evaluated viscometrically, and the measured inherent viscosities were in the range of $0.46-0.71 \mathrm{dL} / \mathrm{g}$. These polyamides were readily soluble in many organic solvents. These polymers still keep good thermal stability with high glass transition temperatures in the range of $310-345^{\circ} \mathrm{C}$ and the decomposition temperature under the nitrogen atmosphere for $10 \%$ weight-loss temperatures in excess of $488^{\circ} \mathrm{C}$.
\end{abstract}

\section{Introduction}

Due to the increasing demands for high-performance polymers as a replacement for ceramics or metals in the microelectronic, aerospace and automotive industries, and thermally stable polymers have received much interest over the past decade. Polyimides and their copolymers are certainly one of the most useful classes of high-performance polymers, which have found many applications in industries [1-3]. Aromatic polyimides are an important class of heterocyclic polymers with remarkable heat resistance and superior mechanical and electrical properties, and also durability [4-6]. Poor thermoplastic fluidity and solubility are the major problems in wide application of polyimides. This makes it impossible for most polyimides to be directly processed in their imidized forms; thus, their applications have been restricted in some fields. Processable engineering plastics possessing moderately high softening temperatures and/or solubility in some organic solvents are required for practical use. Therefore, various efforts have been focused on the preparation of soluble and/or thermoplastic polyimides, while still maintaining the excellent thermal and mechanical properties. Typical approaches have been employed to improve the processability of these polyimides including the incorporation of flexible links [7], bulky pendant or cardo groups [8], kinked or unsymmetrical structures [9], and spiroskeletons [10] into the polymer chain. These modifications lower the melting temperature and lead to soluble and amorphous polymers. In general, amorphous polymers have a lower softening temperature $\left(T_{g}\right)$ and improved solubility with respect to their crystalline analogues. Some of the block copolymers composed of polyethers and polyamides have already been commercialized as thermoplastic elastomers [11]. A number of synthetic routes for polyether-polyimide block copolymers have been known [12]. Ether linkages inserted in the main chains provide them with significantly lower energy of internal rotation. 1,2-dihydro-4-(4-hydroxyphenyl) $(2 \mathrm{H})$ phthalazinones as bisphenol-like monomers were introduced by Berard and Hay [13], and then a number of polymers such as poly(phthalazinone ether)s, polyamides, polyimides, and polyesters have been developed from the series of monomer 
[14-18]. The incorporation of the twisted, noncoplanar structure into the polymer backbone would reduce the chain packing efficiency and crystallinity which could increase solubility. On the other hand, polycondensation reactions are traditionally performed in polar high-boiling-point organic solvents such as N-methyl-2-pyrrolidone (NMP), N,Ndimethylacetamide (DMAc), and N,N-dimethylformamide (DMF), which generally cause several ecological disadvantages further than the imposition of the overcost on synthetic methods. So development of the effective techniques for replacing or removing hazardous materials is one of the recent environmental issues $[19,20]$. Recently, ionic liquids (ILs) have been of interest in many fields of chemistry because of their exclusive properties such as solubility, nonvolatility, high reactivity, low flammability, and possibility of recycling [21-24]. Nonvolatile nature and stability at high temperature make the ILs excellent candidates for the use as polycondensation reactions medium [25-27]. Furthermore, it has been shown that ILs have catalytic effect on the polymerization progresses, resulting from the removal of some of the additives which are essential in conventional polymerization methods [28, 29].

In the present paper the prepared dicarboxylic acid containing phthalazinone (DHPZ) moiety in the main chain [1] was directly polycondensed with various aromatic diamines in an ionic liquid medium to produce a series of organosoluble polyamides. The properties of these polymers, such as solubility and thermal stability of these polymers are also discussed herein.

\section{Experimental}

2.1. Materials. 4-[4-(4-Carboxy phenoxy)-naphthyl]-2-(4carboxyphenyl) phthalazin-1-one (1) was prepared as reported [1]. 1,4-phenylenediamine (2a), 1,3-phenylenediamine (2b), 2,6-pyridinediamine (2c), 3,5-pyridinediamine (2d), 2,5-diaminotoluene (2e), and 4,4'-diaminodiphenylether (2f) were purified by sublimation, $4,4^{\prime}$-diaminodiphenylmethane $(2 \mathrm{~g})$ and 4,4'-diaminobiphenyl (2h) were purified by recrystallization from water. DMAc was purified by distillation under reduced pressure over barium oxide. Triphenyl phosphite (TPP) was purified by distillation under reduced pressure. All other materials were reagent-grade and used without further.

2.2. Equipments. Proton nuclear magnetic resonance ${ }^{1} \mathrm{HNMR}(400 \mathrm{MHz})$ spectra were recorded on a Bruker AM instrument (Bruker, Rheinstetten, Germany) using DMSO$\mathrm{d}_{6}$ as solvent. The FT-IR adsorption spectra were recorded on a Shimadzu FT-IR-680 spectrophotometer with $\mathrm{KBr}$ pellets. Elemental analyses were made on a Heraeus CHNS-RAPID instrument. Ultraviolet-visible (UV-vis) spectra of the dilute $\mathrm{N}, \mathrm{N}$-dimetheylformamide (DMF) solution were recorded on a JASCO V-570 spectrophotometer. Inherent viscosities of polymer solution $(0.5 \% \mathrm{w} / \mathrm{v})$ in DMF were determined at $25^{\circ} \mathrm{C}$ by a standard procedure using a Cannon Fenske Routine viscometer (Cannon, Mainz, Germany). Melting points were measured in open capillaries with a gallenkamp instrument. Thermal gravimetric analysis (TGA) data for polymers were taken on a TGA-Perkin Elmer (Pyris 1) at a heating rate of $10^{\circ} \mathrm{C} / \mathrm{min}$ under $\mathrm{N}_{2}$ atmosphere. Differential scanning calorimetric analysis (DSC) data were recorded on a DSC-PL-1200 instrument under $\mathrm{N}_{2}$ atmosphere.

\subsubsection{Monomer Preparation}

4-[4-(4-Carboxy phenoxy)-naphthyl]-2-(4-carboxyphenyl) phthalazin-1-one (1) Was Prepared as Reported [1]. Yield: 90\%; white powder; $\mathrm{mp} .165-167^{\circ} \mathrm{C}$; IR $\left(\mathrm{KBr}, \mathrm{cm}^{-1}\right): 3070$ (broad, $\mathrm{C}(\mathrm{O}) \mathrm{O}-\mathrm{H}), 1692(\mathrm{C}=\mathrm{O}), 1,239(\mathrm{C}-\mathrm{O}-\mathrm{C}) ;{ }^{1} \mathrm{H}$ NMR $\left(\right.$ DMSO$\left._{-} \mathrm{d}_{6}, \mathrm{ppm}\right): \delta 12.93(\mathrm{~s}, 2 \mathrm{H}), 8.51(\mathrm{~d}, 1 \mathrm{H}), 8.14(\mathrm{~d}$, $1 \mathrm{H}), 8.07(\mathrm{~d}, 2 \mathrm{H}), 8.00(\mathrm{~d}, 2 \mathrm{H}), 7.96(\mathrm{t}, 1 \mathrm{H}), 7.88(\mathrm{~m}, 4 \mathrm{H})$, $7.77(\mathrm{~d}, 1 \mathrm{H}), 7.60(\mathrm{t}, 1 \mathrm{H}), 7.56(\mathrm{t}, 1 \mathrm{H}), 7.34(\mathrm{~d}, 1 \mathrm{H}), 7.31(\mathrm{~d}$, $1 \mathrm{H}), 7.21(\mathrm{~d}, 2 \mathrm{H}) ;{ }^{13} \mathrm{C}$ NMR (DMSO- $\left.\mathrm{d}_{6}, \mathrm{ppm}\right): \delta 166.68$, $166.64,161.05,158.25,151.82,146.26,145.13,133.97$, $133.38,132.33,131.71,129.89,129.59,129.54,128,56$, $128.47,127.99,127.69,126.95,126.86,126.78,126.18$, 125.91, 125.73, 125.71, 121.69, 117.30, 114.75. Calculated for $\mathrm{C}_{32} \mathrm{H}_{18} \mathrm{~N}_{2} \mathrm{O}_{6}$ : C (72.72\%), H (3.81\%), N (5.30\%). Found: C (72.49\%), H (3.77\%), N (5.45\%).

\subsection{Polymer Preparation}

Preparation of PAs via IL Catalysis Polycondensation. The PAs were prepared by the following general procedure: as an example for the preparation of $\mathrm{PA}_{1}, 0.1108 \mathrm{~g}(0.226 \mathrm{mmol})$ of diacid 1 and $0.0244 \mathrm{~g}(0.226 \mathrm{mmol})$ of diamine $2 \mathrm{a}$ were dissolved in $0.15 \mathrm{~g}$ of [1-methyl-3-propyl imidazolium] $\mathrm{Br}$, then $0.15 \mathrm{~mL}(0.565 \mathrm{mmol})$ of triphenyl phosphite (TPP) was added. The whole solution was heated at $110^{\circ} \mathrm{C}$ for $2.5 \mathrm{~h}$. The solution becomes more viscous by progress of the polymerization reaction. The resulting product was dissolved in $1 \mathrm{~mL}$ of DMF and was poured into $25 \mathrm{~mL}$ of stirring methanol, filtered, and dried under vacuum to give $0.1311 \mathrm{~g}$ (97\%) of $\mathrm{PA}_{1}$.

$\left(\mathrm{PA}_{1}\right)$ : white solid; FT-IR $\left(\mathrm{KBr}, \mathrm{cm}^{-1}\right): 3341(\mathrm{C}(\mathrm{O}) \mathrm{N}-\mathrm{H}$, stretching), $1683(\mathrm{C}=\mathrm{O}$, stretching $), 1611(\mathrm{~N}-\mathrm{H}$, bending). Calculated for $\mathrm{C}_{38} \mathrm{H}_{22} \mathrm{~N}_{4} \mathrm{O}_{4}$ : C $(76.24 \%)$, $\mathrm{H}(3.70 \%), \mathrm{N}(9.36 \%)$. Found: C $(76.17 \%), \mathrm{H}$ (3.65\%), N (9.31\%).

$\left(\mathrm{PA}_{2}\right)$ : white solid; FT-IR $\left(\mathrm{KBr}, \mathrm{cm}^{-1}\right): 3339(\mathrm{C}(\mathrm{O}) \mathrm{N}-\mathrm{H}$, stretching $), 1680(\mathrm{C}=\mathrm{O}$, stretching $), 1618(\mathrm{~N}-\mathrm{H}$, bending). Calculated for $\mathrm{C}_{38} \mathrm{H}_{22} \mathrm{~N}_{4} \mathrm{O}_{4}$ : C (76.24\%), $\mathrm{H}(3.70 \%), \mathrm{N}(9.36 \%)$. Found: C (76.19\%), H (3.67\%), N (9.30\%).

$\left(\mathrm{PA}_{3}\right)$ : white solid; FT-IR $\left(\mathrm{KBr}, \mathrm{cm}^{-1}\right): 3351(\mathrm{C}(\mathrm{O}) \mathrm{N}-\mathrm{H}$, stretching $), 1674(\mathrm{C}=\mathrm{O}$, stretching $), 1600(\mathrm{~N}-\mathrm{H}$, bending). Calculated for $\mathrm{C}_{37} \mathrm{H}_{21} \mathrm{~N}_{5} \mathrm{O}_{4}$ : C $(74.12 \%)$, $\mathrm{H}(3.53 \%), \mathrm{N}(11.68 \%)$. Found: C (74.04\%), H (3.48\%), N (11.59\%).

$\left(\mathrm{PA}_{4}\right)$ : white solid; FT-IR $\left(\mathrm{KBr}, \mathrm{cm}^{-1}\right): 3350(\mathrm{C}(\mathrm{O}) \mathrm{N}-\mathrm{H}$, stretching), $1677(\mathrm{C}=\mathrm{O}$, stretching $), 1598(\mathrm{~N}-\mathrm{H}$, bending). Calculated for $\mathrm{C}_{37} \mathrm{H}_{21} \mathrm{~N}_{5} \mathrm{O}_{4}$ : $\mathrm{C}(74.12 \%)$, H $(3.53 \%), \mathrm{N}(11.68 \%)$. Found: C $(74.10 \%), \mathrm{H}$ (3.44\%), N (11.53\%). 


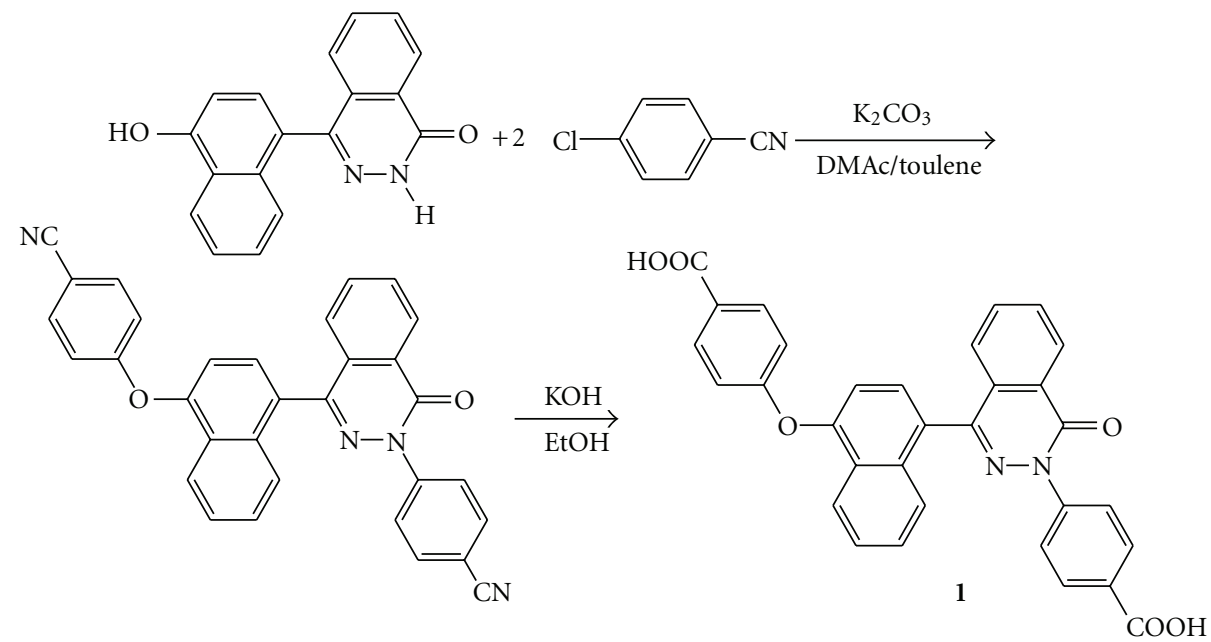

Scheme 1: Preparation of the unsymmetrical diacid containing phthalazinone moiety.
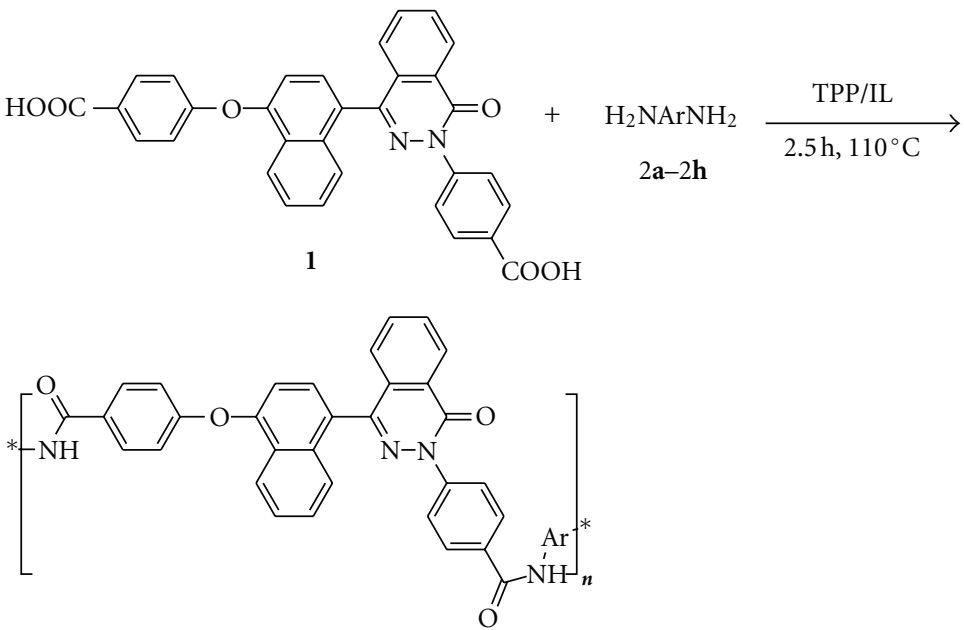

$\mathrm{PA}_{1-8}$

Ar:<smiles>Cc1cccc(C)c1</smiles>

$2 b$<smiles>Cc1cccc(C)n1</smiles>

2c<smiles>Cc1cncc(C)c1</smiles>

2d<smiles>Cc1ccc(Oc2ccc(C)cc2)cc1</smiles>

$2 e$ 2f<smiles>Cc1ccc(Cc2ccc(C)cc2)cc1</smiles>

$2 \mathrm{~g}$

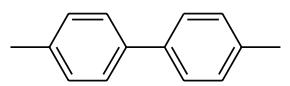

$2 \mathrm{~h}$

Scheme 2: Ionic liquid-catalyzed preparation of aromatic polyamides.

$\left(\mathrm{PA}_{5}\right)$ : white solid; FT-IR $\left(\mathrm{KBr}, \mathrm{cm}^{-1}\right): 3335(\mathrm{C}(\mathrm{O}) \mathrm{N}-$ $\mathrm{H}$, stretching), $2867\left(\mathrm{CH}_{3}\right.$, stretching $), 1680(\mathrm{C}=\mathrm{O}$, stretching), 1615 ( $\mathrm{N}-\mathrm{H}$, bending). Calculated for $\mathrm{C}_{39} \mathrm{H}_{24} \mathrm{~N}_{4} \mathrm{O}_{4}$ : C (76.46\%), $\mathrm{H}$ (3.95\%), $\mathrm{N}$ (9.14\%). Found: C (76.41\%), H (3.89\%), N (9.11\%).

$\left(\mathrm{PA}_{6}\right)$ : white solid; FT-IR $\left(\mathrm{KBr}, \mathrm{cm}^{-1}\right): 3337(\mathrm{C}(\mathrm{O}) \mathrm{N}-$ $\mathrm{H}$, stretching), 1635 ( $\mathrm{C}=\mathrm{O}$, stretching), $1598(\mathrm{~N}-$ $\mathrm{H}$, bending), 1227 and 1124 (C-O-C, stretching).
${ }^{1} \mathrm{H}$ NMR (DMSO-d $\left.{ }_{6}, \mathrm{ppm}\right): \delta 10.66(\mathrm{~N}-\mathrm{H}, 1 \mathrm{H})$, $10.52(\mathrm{~N}-\mathrm{H}, 1 \mathrm{H}), 8.52(1 \mathrm{H}), 8.32(2 \mathrm{H}), 8.21(1 \mathrm{H})$, 8.01-8.18 (4H), 7.78-8.01 (6H), 7.51-7.66 (2H), $7.32(4 \mathrm{H}), 7.12(4 \mathrm{H})$. Calculated for $\mathrm{C}_{44} \mathrm{H}_{26} \mathrm{~N}_{4} \mathrm{O}_{5}$ : C (76.51\%), H (3.79\%), N (8.11\%). Found: C (76.48\%), H (3.76\%), N (8.09\%).

$\left(\mathrm{PA}_{7}\right)$ : white solid; FT-IR $\left(\mathrm{KBr}, \mathrm{cm}^{-1}\right)$ : $3344(\mathrm{C}(\mathrm{O}) \mathrm{N}-$ $\mathrm{H}$, stretching), $2858\left(\mathrm{CH}_{2}\right.$, stretching $), 1677(\mathrm{C}=\mathrm{O}$, 


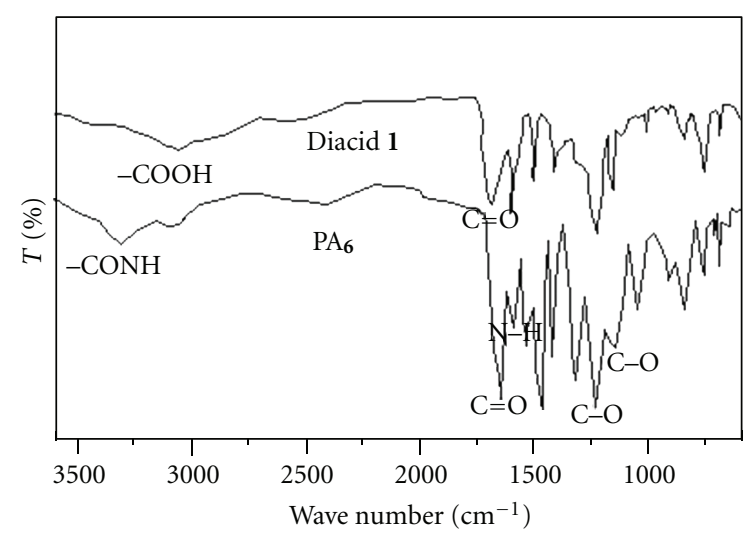

FIgURe 1: FT-IR spectra of diacid (1) and polymer $\mathrm{PA}_{6}$.

stretching), 1602 (N-H, bending). Calculated for $\mathrm{C}_{45} \mathrm{H}_{28} \mathrm{~N}_{4} \mathrm{O}_{4}$ : C (78.47\%), $\mathrm{H}(4.10 \%), \mathrm{N}(8.13 \%)$. Found: C (78.41\%), H (4.07\%), N (8.10\%).

$\left(\mathrm{PA}_{8}\right)$ : white solid; FT-IR $\left(\mathrm{KBr}, \mathrm{cm}^{-1}\right): 3356(\mathrm{C}(\mathrm{O}) \mathrm{N}-\mathrm{H}$, stretching), $1663(\mathrm{C}=\mathrm{O}$, stretching), $1587(\mathrm{~N}-\mathrm{H}$, bending). Calculated for $\mathrm{C}_{44} \mathrm{H}_{26} \mathrm{~N}_{4} \mathrm{O}_{4}$ : $\mathrm{C}(78.33 \%)$, $\mathrm{H}(3.88 \%), \mathrm{N}(8.30 \%)$. Found: C (78.24\%), H $(3.77 \%), \mathrm{N}(8.28 \%)$.

\section{Results and Discussion}

3.1. Monomer Preparation. As shown in Scheme 1, the phthalazinone-containing aromatic dicarboxylic acid was prepared by alkaline hydrolysis of the corresponding dinitrile compound resulting from the nucleophilic substitution reaction of 4-(4-hydroxynaphthalenyl) phthalazin-1-one with pchlorobenzonitrile.

All preparaed compounds were characterized by elemental analysis, FT-IR and ${ }^{1} \mathrm{H}$ NMR spectroscopy with satisfied results. A broad $\mathrm{O}-\mathrm{H}$ absorption of diacid (1) appeared in the region of $2600-3500 \mathrm{~cm}^{-1}$ and that of $\mathrm{C}=\mathrm{O}$ stretching at $1689 \mathrm{~cm}^{-1}$ (Figure 1). In ${ }^{1} \mathrm{H}$ NMR (DMSO- $\mathrm{d}_{6}, \mathrm{ppm}$ ), the corresponding peak to $\mathrm{CO}(\mathrm{O}-\mathrm{H})$ appeared at $\delta 12.93(\mathrm{~s}$, $2 \mathrm{H})$.

3.2. Polymer Preparation. Polymerization of diacid (1) with stoichiometric amount of different aromatic diamines (2a2h) was carried out in [1-methyl-3-propyl imidazolium $] \mathrm{Br}$ both as solvent and catalyst outlined in Scheme 2.

In addition to provide a safe and green reaction medium, IL has also catalytic effect on polymerization reaction because polyamidations did not progress in the absence of either IL or TPP and the existence of both IL and TPP at the same time was essential for the polycondensation. A comparison between this method and the conventional method proves that the PAs prepared via IL method encompass higher inherent viscosities and yields. Furthermore, the use of IL causes reduced overall cost of preparation and cleaner reaction. Utilization of ILs is often motivated by safety and environmental considerations, where the eligible volatility and nonflammability of ILs make them promising green replacements for more hazardous molecular solvents and overcomes the trouble of solvent evaporation that exists with the long-term use of volatile solvents in organic synthesis. The high polarity and viscosity of ILs greatly increases the propagation rate constant $\left(k_{p}\right)$ and decreases the termination rate constant $\left(k_{t}\right)$ in polymerization; consequently, polymers with higher molecular weight and narrower polydisperse are achieved in ILs. All polyamidations proceeded in a homogeneous system throughout the reaction, and the polyamides were isolated in quantitative yields. The yields and inherent viscosities of the resulting polyamides are summarized in Table 1.

Inherent viscosities of the polyamides ranged from $0.46-$ $0.71 \mathrm{dL} / \mathrm{g}$, indicative of the formation of high molecular weights. The structures of these polyamides were confirmed by IR spectroscopy. For example, polymer $\mathrm{PA}_{6}$ (Figure 1) showed characteristic absorptions of amide group occurred at $3337(\mathrm{C}(\mathrm{O}) \mathrm{N}-\mathrm{H}$, stretching $), 1635(\mathrm{C}=\mathrm{O}$, stretching $)$, and 1598 (N-H, bending) $\mathrm{cm}^{-1}$. The ${ }^{1} \mathrm{H}$ NMR spectrum of $\mathrm{PA}_{6}$ was showed in Figure 2.

The absorption peaks at 10.5 and $10.6 \mathrm{ppm}$ was assigned to the $\mathrm{N}-\mathrm{H}$ protons. Thermal properties and glass transitions temperature $\left(T_{g}\right)$ of the polymers were evaluated with TGA and DSC, respectively (Figures 3 and 4), and the characteristic data are summarized in Table 2 . The $T_{g}$ value of $\mathrm{PA}_{1-8}$ were in the range of $310-345^{\circ} \mathrm{C}$. In addition more than half of the polymers weight remained at $600^{\circ} \mathrm{C}$ (char yields). The excellent thermal stabilities may be due to the presence of very rigid aromatic heterocyclic backbone.

3.3. Organosolubility. The solubility behavior of the new aromatic polyamides was determined at concentration of $5 \%(W / V)$ in a number of solvents. Almost all prepared polyamides exhibited excellent solubility in polar aprotic solvents such as NMP, DMF, DMAc, dimethyl sulfoxide (DMSO), and even in less polar solvents like Py and mcresol. High tendency to pack the polymer chains is the predominant origin of insolubility of common PAs because of ability to create high density of interchain H-bonds. In the case of our prepared PAs, the high solubility is attributed to the presence of twist and noncoplanar aromatic heterocyclic moiety in the polymer backbone, which interrupt the regular packing of polymer chains. In addition, the more flexible ether group was introduced in the polymer backbone are especially effective for the high solubility.

\section{Conclusion}

Replacement of the toxic volatile organic solvents with several ecological disadvantages by a green, safe, and ecofriendly reaction medium is the main aspect of this investigation. Therefore, direct polycondensations of diacid monomer (1) and several aromatic diamines have been investigated in IL medium, which acts as a green solvent and a reaction catalyst. Comparison with the reported direct method [1] indicates that IL in combination with TPP is the superior polyamidation agent. On the other hand, in the case of ILcatalyzed polyamidation, removal of some chemicals such 


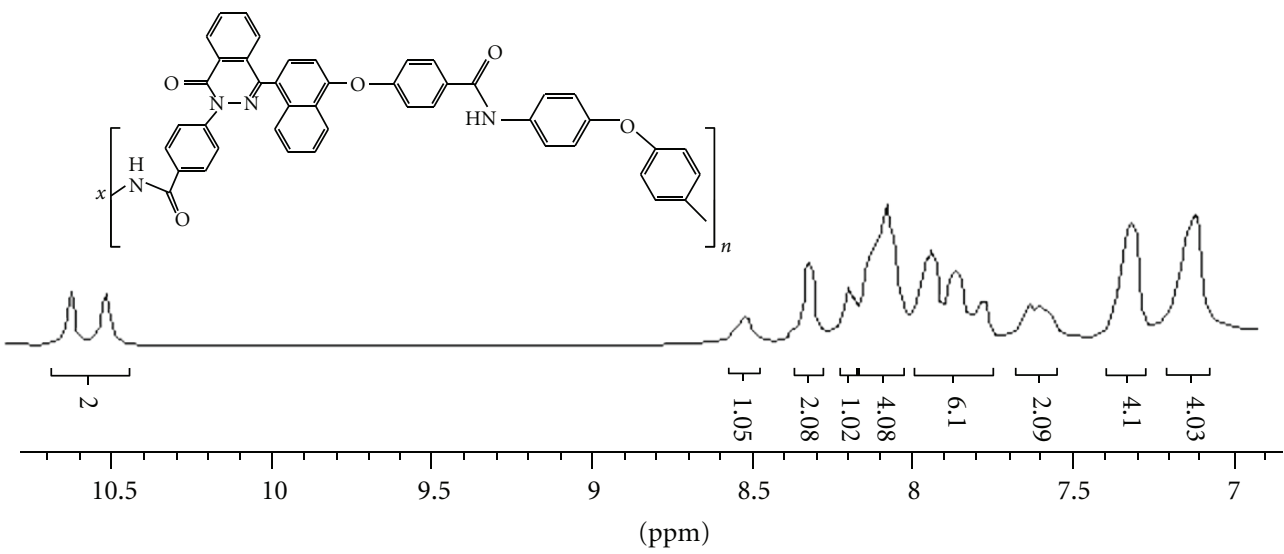

FIgURE 2: ${ }^{1} \mathrm{H}$ NMR spectrum of polymer $\mathrm{PA}_{6}$ in DMSO-d $\mathrm{d}_{6}$.

TABLE 1: Inherent viscosity and yield of polyamids.

\begin{tabular}{|c|c|c|c|c|}
\hline \multirow{2}{*}{ Polymer } & \multicolumn{2}{|c|}{ IL catalysis polycondensation } & \multicolumn{2}{|c|}{ Conventional polycondensation [1] } \\
\hline & Yield $(\%)$ & $\dot{\eta}_{\text {inh }}\left(\mathrm{dl} \mathrm{g}^{-1}\right)^{\mathrm{a}}$ & Yield $(\%)$ & $\dot{\eta}_{\text {inh }}\left(\mathrm{dl} \mathrm{g}^{-1}\right)^{\mathrm{a}}$ \\
\hline $\mathrm{PA}_{1}$ & 97 & 0.69 & 99.1 & 0.63 \\
\hline $\mathrm{PA}_{2}$ & 95 & 0.56 & - & - \\
\hline $\mathrm{PA}_{3}$ & 93 & 0.54 & - & - \\
\hline $\mathrm{PA}_{4}$ & 90 & 0.48 & - & - \\
\hline $\mathrm{PA}_{5}$ & 92 & 0.46 & - & - \\
\hline $\mathrm{PA}_{6}$ & 98.8 & 0.64 & 98.4 & 0.58 \\
\hline $\mathrm{PA}_{7}$ & 95 & 0.49 & - & - \\
\hline $\mathrm{PA}_{8}$ & 97 & 0.71 & - & - \\
\hline
\end{tabular}

${ }^{\text {a }}$ Measured at a concentration of $0.5 \mathrm{~g} / \mathrm{dL}$ in DMAc at $30^{\circ} \mathrm{C}$.

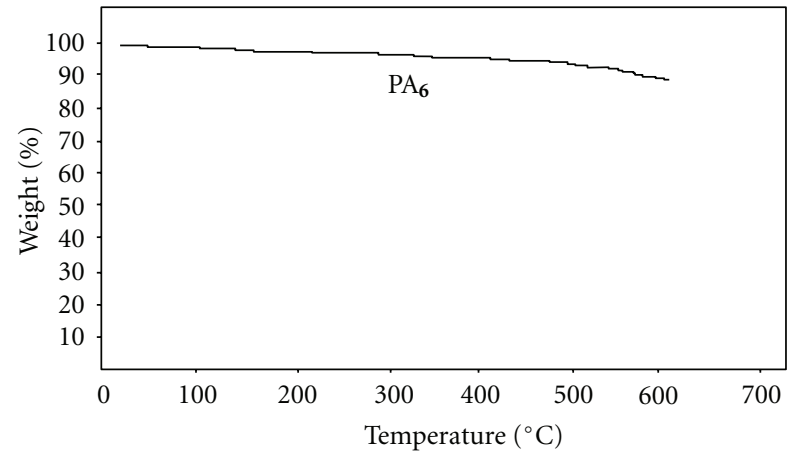

Figure 3: TGA curve of $\mathrm{PA}_{6}$.

as NMP, $\mathrm{CaCl}_{2}$, and Py, which are essential in conventional methodologies, decreases the cost of polymerization as well as the environmental pollutions, considerably. Here a series of polyamides containing phthalazione were prepared from diacid (1) with various aromatic diamines by ionic liquid catalyzed method. The results indicated that adding asymmetrical and noncoplanar heterocyclic unit into polymer

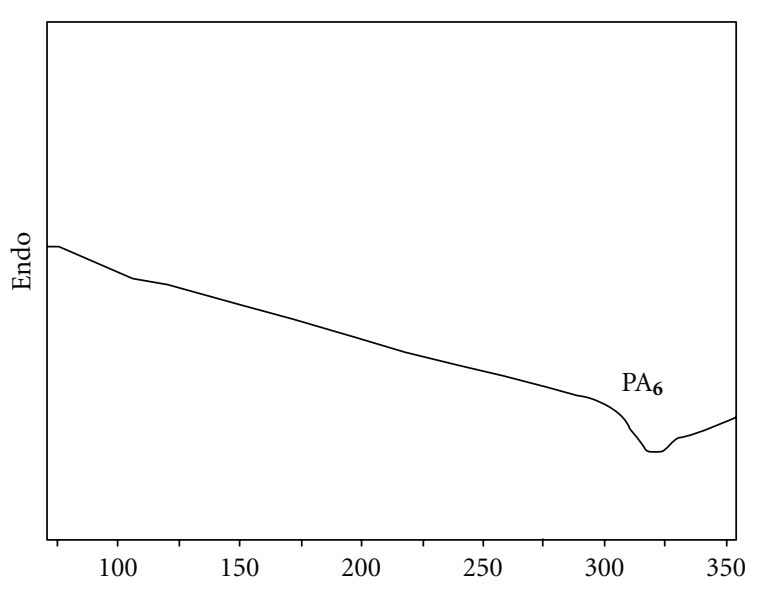

Figure 4: DSC curve of $\mathrm{PA}_{6}$.

backbone improved the solubility of polyamides with the retention of the thermostability. The properties of these polyamides make them attractive for practical applications such as processable high performance polymeric materials. 
TABLE 2: Thermal properties of $\mathrm{PA}_{1-8}$.

\begin{tabular}{|c|c|c|c|c|c|c|}
\hline \multirow{2}{*}{ Polymer } & \multicolumn{3}{|c|}{ IL catalysis polycondensation } & \multicolumn{3}{|c|}{ Conventional polycondensation [1] } \\
\hline & ${ }^{\mathrm{a}} T_{10 \%}$ & ${ }^{\mathrm{b}} T_{g}\left({ }^{\circ} \mathrm{C}\right)$ & ${ }^{\mathrm{c}}$ Char yield & $T_{10 \%}$ & $T_{g}\left({ }^{\circ} \mathrm{C}\right)$ & Char yield \\
\hline $\mathrm{PA}_{1}$ & 497 & 323 & 61 & 509 & 338 & - \\
\hline $\mathrm{PA}_{2}$ & 458 & 310 & 62 & - & - & - \\
\hline $\mathrm{PA}_{3}$ & 511 & 321 & 56 & - & - & - \\
\hline $\mathrm{PA}_{4}$ & 521 & 317 & 53 & - & - & - \\
\hline $\mathrm{PA}_{5}$ & 498 & 312 & 42 & - & - & - \\
\hline $\mathrm{PA}_{6}$ & 565 & 324 & 87 & 511 & 311 & - \\
\hline $\mathrm{PA}_{7}$ & 488 & 332 & 50 & - & - & - \\
\hline $\mathrm{PA}_{8}$ & 578 & 345 & 68 & - & - & - \\
\hline
\end{tabular}

${ }^{a}$ Temperature at which $10 \%$ weight loss was recorded by TGA at a heating rate of $10^{\circ} \mathrm{C} /$ min under nitrogen atmosphere. ${ }^{b} \mathrm{Glass}$ transition temperature recorded by DSC at a heating rate of $10^{\circ} \mathrm{C} / \mathrm{min}$ under nitrogen atmosphere. ${ }^{\circ}$ Percentage weight of material left after TGA analysis at maximum temperature $600^{\circ} \mathrm{C}$ under nitrogen atmosphere.

\section{Acknowledgment}

The authors gratefully acknowledge the funding support received for this project from Payame Noor University.

\section{References}

[1] J. Tan, C. Wang, W. Peng, G. Li, and J. M. Jiang, "Synthesis, characterization, and properties of novel aromatic polyamides containing phthalazinone moiety," Polymer Bulletin, vol. 62, no. 2, pp. 195-207, 2009.

[2] K. L. Mittal, Polyimides: Synthesis, Characterization and Application, Plenum, New York, NY, USA, 1984.

[3] M. J. M. Abade, Ed., Polyimides and Other High-Temperature Polymers, Elsevier, New York, NY, USA, 1991.

[4] A. Banihashemi and A. Abdolmaleki, "Novel aromatic polyimides derived from benzofuro[2,3-b]benzofuran-2,3,8,9tetracarboxylic dianhydride (BBTDA)," European Polymer Journal, vol. 40, no. 8, pp. 1629-1635, 2004.

[5] M. K. Ghosh and K. L. Mittal, Eds., Polyimide: Fundamentals and Applications, Marcel Dekker, New York, NY, USA, 1996.

[6] D. Wilson, M. D. Stenzenberger, and P. Hergenrother, Polyimides, Blackie, Glasgow, UK, 1990.

[7] S. Tamai, A. Yamaguchi, and M. Ohta, "Melt processible polyimides and their chemical structures," Polymer, vol. 37, no. 16, pp. 3683-3692, 1996.

[8] S. H. Hsiao and C. T. Li, "Synthesis and characterization of new adamantane-based polyimides," Macromolecules, vol. 31, no. 21, pp. 7213-7217, 1998.

[9] F. Li, J. J. Ge, P. S. Honigfort et al., "Dianhydride architectural effects on the relaxation behaviors and thermal and optical properties of organo-soluble aromatic polyimide films," Polymer, vol. 40, no. 18, pp. 4987-5002, 1999.

[10] D. S. Reddy, C. H. Chou, C. F. Hsu, and G. H. Lee, "Synthesis and characterization of soluble poly(ether imide)s based on 2,2' -bis(4-aminophenoxy)-9,9' -spirobifluorene," Polymer, vol. 44, pp. 557-563, 2003.

[11] N. R. Legge, G. Holden, and H. E. Schroeder, Thermoplastic Elastomers, Hanser, New York, NY, USA, 1987.

[12] A. Noshay and I. E. McGrath, Block Copolymers, Academic Press, New York, NY, USA, 1977.

[13] N. Berard and A. S. Hay, "Division of Polymer Chemistry, American Chemical Society," Polymer Preparation, vol. 34, p. $148,1993$.
[14] J. Van Wang, G. X. Liao, C. Liu, and X. G. Jian, "Poly(ether imide)s derived from phthalazinone-containing dianhydrides," Journal of Polymer Science A, vol. 42, no. 23, pp. 60896097, 2004.

[15] L. Cheng, H. Wu, L. Ying, X. L. Yang, and X. G. Jian, "New soluble aromatic polyamides from non-symmetrical extended diacid containing a phthalazinone moiety," Designed Monomers and Polymers, vol. 7, pp. 225-234, 2004.

[16] X. H. Li and A. S. Hay, "Synthesis of a high molecular weight fluorinated poly(phthalazinone ether) by self-condensation of an AB-type monomer," Macromolecules, vol. 39, pp. 37143716, 2005.

[17] X. H. Zhang, S. Chen, Y. Q. Min, and G. R. Qi, "Synthesis of novel bisphenol containing phthalazinone and azomethine moieties and thermal properties of cured diamine/bisphenol/DGEBA polymers," Polymer, vol. 47, no. 6, pp. 1785-1795, 2006.

[18] L. Cheng, L. Ying, J. Feng, C. Y. Wang, J. L. Li, and Z. Xu, "Novel heterocyclic poly(arylene ether ketone)s: synthesis and polymerization of 4 - $\left(4^{\prime}\right.$-hydroxyaryl $)(2 H)$ phthalazin-1-ones with methyl groups," Journal of Polymer Science A, vol. 45, pp. 1525-1535, 2007.

[19] M. B. Talawar, R. Sivabalan, T. Mukundan et al., "Environmentally compatible next generation green energetic materials (GEMs)," Journal of Hazardous Materials, vol. 161, no. 2-3, pp. 589-607, 2009.

[20] S. Paria, "Surfactant-enhanced remediation of organic contaminated soil and water," Advances in Colloid and Interface Science, vol. 138, no. 1, pp. 24-58, 2008.

[21] S. Keskin, D. Kayrak-Talay, U. Akman, and Ö. Hortaçsu, "A review of ionic liquids towards supercritical fluid applications," Journal of Supercritical Fluids, vol. 43, no. 1, pp. 150180, 2007.

[22] H. Nakagawa, Y. Fujino, S. Kozono et al., "Application of nonflammable electrolyte with room temperature ionic liquids (RTILs) for lithium-ion cells," Journal of Power Sources, vol. 174, no. 2, pp. 1021-1026, 2007.

[23] A. Abdolmaleki, "Synthesis and characterization of some new polyhydrazides by direct polycondensation in ionic liquid," Iranian Polymer Journal, vol. 16, no. 11, pp. 741-751, 2007.

[24] Q. Shi, Y. Zhang, G. Jing, and J. Kan, "Properties of polyaniline synthesized in ionic liquid (1-ethyl-3- methylimidazoliumethyl sulphate)," Iranian Polymer Journal, vol. 16, no. 5, pp. 337-344, 2007. 
[25] C. Arbizzani, F. Soavi, and M. Mastragostino, "A novel galvanostatic polymerization for high specific capacitance poly(3-methylthiophene) in ionic liquid," Journal of Power Sources, vol. 162, no. 1, pp. 735-737, 2006.

[26] A. S. Shaplov, E. I. Lozinskaya, I. L. Odinets et al., "Novel phosphonated poly(1,3,4-oxadiazole)s: synthesis in ionic liquid and characterization," Reactive and Functional Polymers, vol. 68, no. 1, pp. 208-224, 2008.

[27] J. T. Gorke, K. Okrasa, A. Louwagie, R. J. Kazlauskas, and F. Srienc, "Enzymatic synthesis of poly(hydroxyalkanoates) in ionic liquids," Journal of Biotechnology, vol. 132, no. 3, pp. 306313, 2007.

[28] S. Mallakpour and E. Kowsari, "Ionic liquids as novel solvents and catalysts for the direct polycondensation of $\mathrm{N}, \mathrm{N}^{\prime}-\left(4,4^{\prime}\right.$ -Oxydiphthaloyl)bis-L-phenylalanine diacid with various aromatic diamines," Journal of Polymer Science A, vol. 43, no. 24, pp. 6545-6553, 2005.

[29] S. Mallakpour and E. Kowsari, "Microwave heating in conjunction with ionic liquid as a novel method for the fast synthesis of optically active poly(amideimide)s derived from $\mathrm{N}, \mathrm{N}^{\prime}-\left(4,4^{\prime}\right.$-hexafluoroisopropylidenediphthaloyl)-bisLmethionine and various aromatic diamines," Iranian Polymer Journal, vol. 15, p. 239, 2006. 

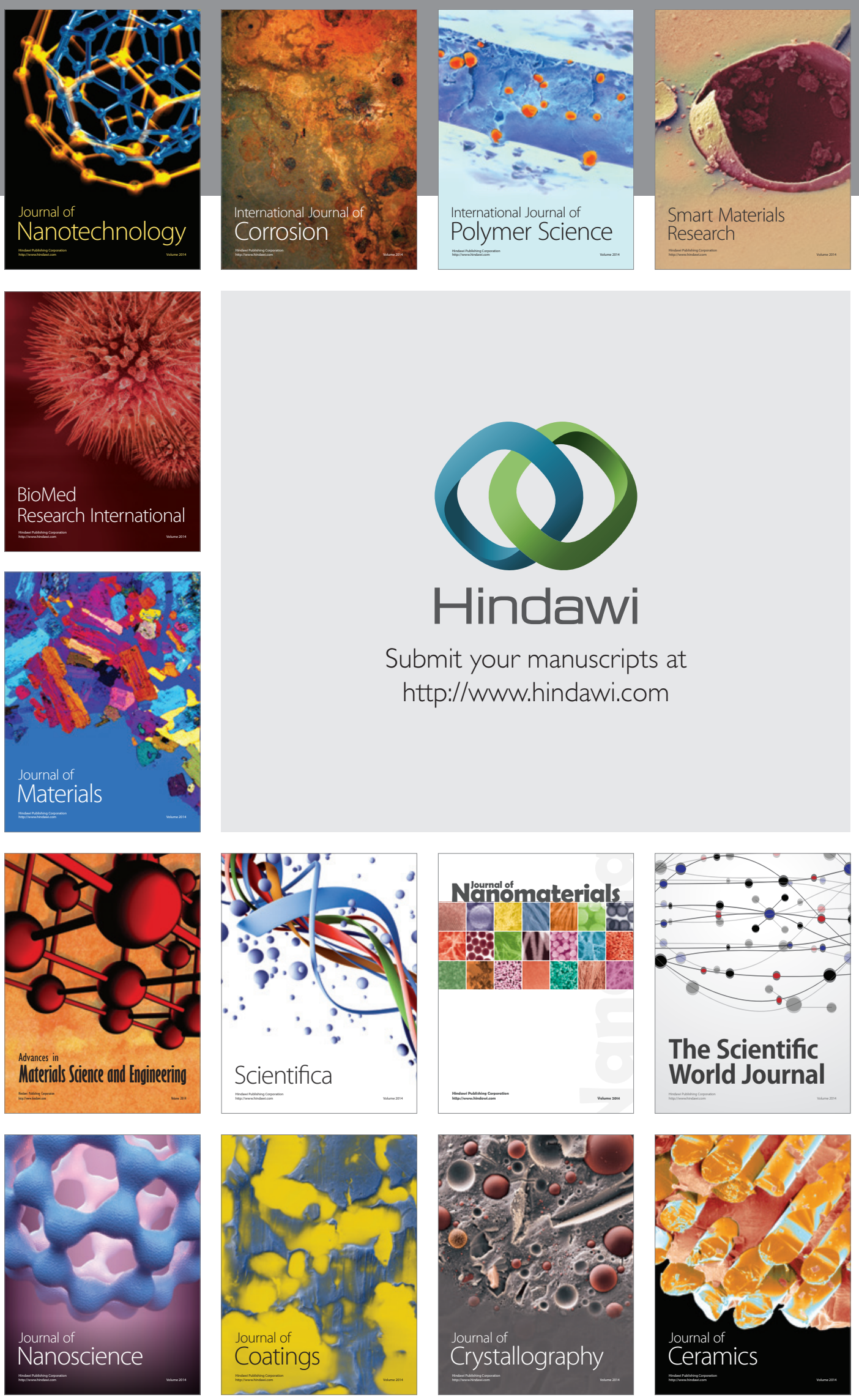

The Scientific World Journal

Submit your manuscripts at

http://www.hindawi.com

\section{World Journal}

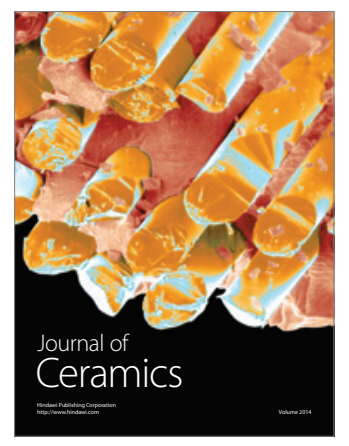

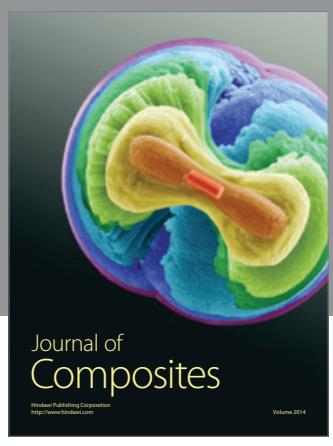
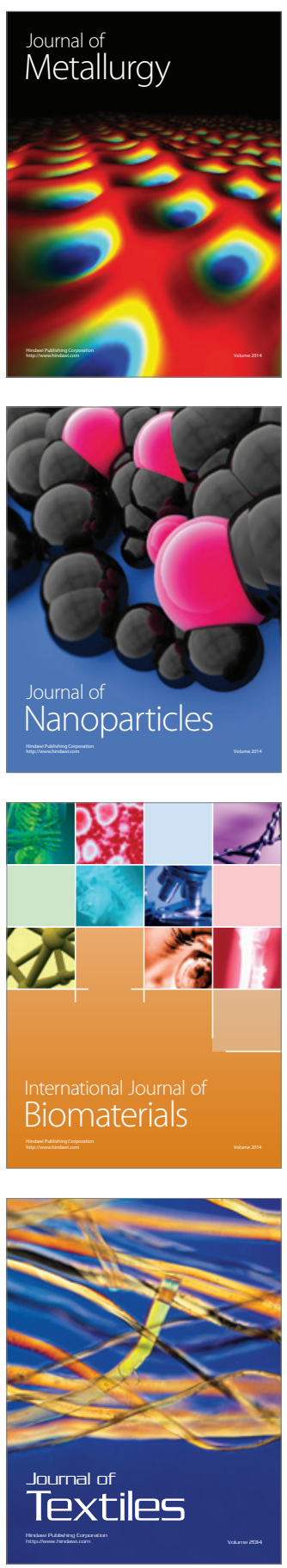